\title{
Cuisine and Dishes in Use During the Prophet Muhammed Era (A.D. 569-632)
}

Sevim Demir AKGÜN, Phd. Cand.

Institute Social Sciences, Sakarya University, Turkey

Prof. Dr. Levent ÖZTÜRK

Faculty of Theology, Department of Islamic History and Arts, Sakarya University, Turkey

\begin{abstract}
Each society has a unique cuisine and taste which has been developed over time. Furthermore, each region and climate offer different options, health and life perception varies in each society. In the Arabian Peninsula where The Prophet Muhammad lived, cuisine was shaped according to the region, climate and life perception according to conditions of the era. Indeed, The Prophet Muhammad was a human being lived in Arabian region. He was in close relation with his own society's cuisine in terms of personal taste before he conveyed the Islamic religion. Islam as a religion has contributed to daily life of people in terms of different point of views beside perception about world blessings. In this text, variety of foods consumed in Arabian Peninsula, distribution of these according to types and variety of dishes, pots and pans that were used during The Prophet Muhammad era was mentioned. This study aimed to enlighten whether religion has an influence on cuisine and Islamic religion suggests a life devoid of food and drink. ${ }^{1}$
\end{abstract}

Keywords: The Prophet Muhammad, Cuisine, Foods, Dishes, Arabian Kitchen.

\section{Introduction}

The Prophet Muhammad who described provision of after death (zād al-āhirah) as the most beneficial of all provisions did not recommend a path without eating and drinking. He did not approve imitation of Cristian and Buddhists priests who kept themselves away from some foods. He preferred to eat everything he liked in the frame of halal foods (Islamic dietary laws by Allah which control the preparation of foods) and the potential of the era.

The most surprising thing for nonbelievers of Muhammad in Meccan society was that the prophet who had been sent them ate and drank (Qur'ān, Furqān 25/7, 20). The foods which had place in The Prophet Muhammad's table were as follows:

\section{The Foods in Cuisine of Muhammad's Era}

\subsection{Meats}

The Prophet Muhammad talked about meat as precious meal of both this world and after death. At that era, meat from camel, sheep, goat and cow was consumed. The most consumed meat among Arabs was certainly from camel. In addition to what was mentioned, meat from rabbit, chicken, bustard and fish was utilized. The Prophet Muhammad liked forelimbs of sheep and prefered this part over others. It was reported that he took the cooked forelimbs and ate with hand (Ibn Māja, At'ima, 27, 28; Tirmidhī, At'ima, 33; Abū Dāwūd, At'ima, 21).

The viscera from animals was consumed too. The liver from sheep and camel was one of the favorites. The Prophet Muhammad ate the liver of a slaughtered sheep with bread. He also liked cooked brain served to him. Aisha, his wife, reported that they buried trotter to preserve them and unburied them to prepare dish (Bukhārī, At'ima, 5; Muslim, Zakāh, 52, 54; Ibn Māja, Attima, 31; Shāmī, VII, 297).

\footnotetext{
${ }^{1}$ This article was produced from the unpublished master thesis called 'The Cuisine in Muhammad's Era' (Sakarya University, Institute Social Sciences, Sakarya 2007) written by Sevim Demir Akgün and supervised by Prof. Dr. Levent Öztürk. )
} 
They were familiar to fish however it was not consumed often. It was mentioned in Sif al-Bahr (Habat) Sariyyah (A.H. 8/A.D. 629) that pieces of a whale casted up the shore was dried and served to The Prophet Muhammad and he ate this meat (Ibn Sa'd, III, 411; Nasāī, Said, 35).

Among the dishes with meat, tirit was the most favorable, The Prophet Muhammad called it as the king of the dishes. Tirit was a dish with bread socked in broth. Sometimes, big pieces of meat was added. Tirit with meat was also served to The Prophet Muhammad. Tirit could be prepared with butter too. The mother of Zaid ibn Sābit prepared tirit with butter for The Prophet Muhammad when he arrived to Madīnah (Ibn Sa'd, III, 614; Abū Dāwūd, At'ima, 23; Shāmī, VII, 305).

Meat used to be fried on the fire. The Prophet Muhammad also liked fried camel meat. Sometimes, pieces of meat was cooked in the smoked fire. Meat was served boiled too. Putting into vinegar was a way of preserving meat for longer times. During hijrah, a dish which its meat was kept in vinegar, was served to The Prophet Muhammad. Meat cooked with cracked wheat (cashīsh, bulgūr) was a kind of dish that The Prophet Muhammad liked. Meat was marinated with salt, vinegar and spices for preserving long time. The Prophet Muhammad described himself as a son of mother who ate dried meat and he liked dried meat (Ibn Sa'd, IV, 312; Ibn Māja, At'ima, 30; Shāmī, VII, 234, 302).

\subsection{Vegetables}

Vegetables also took place in The Prophet Muhammad's table. Zucchini, onion, chard, garlic, leek, mushroom and turnip were among them. A tailor from Madinnah prepared a dish with meat and zucchini. The Prophet Muhammad preferred the zucchini in this dish and host put zucchini close to The Prophet Muhammad (Bukhārī, At'ima, 25, 37; Ibn Māja, At'ima, 35; Ahmad ibn Hanbal, III, 108, 174, 160, 204, 264).

A dish prepared with chard and barley without any meat or oil was a favourable dish eaten by Muslims from Madīnah after Friday (Jumu'ah) prayer (Bukhārī, At'ima, 17; Jawād Ali, VII, 60). It was mentioned that the last meal eaten by The Prophet Muhammad was cooked or fried onions. Onion, garlic and leek were also consumed raw. However, it was recommended not to attend prayers after eating those. It was asked not to disturb people with the odor from these foods (Bukhärī, At ima, 49; Ahmad ibn Hanbal, VI, 89; Shāmī, VII, 262; Jawād Ali, VII, 61).

Arabs liked a dish called hais prepared by mixing dates, oil and curd. It was a very practical dish. In return from Haibar (A.H. 7/A.D. 628), hais was the dish served in The Prophet Muhammad's wedding feast (Bukhārī, At'ima, 7, 16, 28; Ibn Manzūr, Vl, 61).

\subsection{Breads}

Bread made from barley consumed more frequently. Wheat was an expensive grain. It was brought by grain producers or traders from Nabatians, Syria. Not everyone could afford to buy it (Jawād Ali, VII, 58). Abū Huraira reported that there was not bread made from wheat in The Prophet Muhammad's table and Anes ibn Mālik reported that he did not witness The Prophet Muhammad's eating this kind of bread. The bread made up of wheat was soft but the bread made up of barley was stiff (Ibn Sa'd, I, 404; Bukhārī, At 'ima, 7; Ibn Māja, At'ima, 45, 49).

\subsection{Soups}

Soup was widespread dish among meals. Cashīsha, Hazīra, Harīsa and barley soup with chard were frequently consumed soups. Cashīsha was made up of grinded grain with meat or dates. Hazira was cooked by adding fine flour to water. Harīsa was known as flour soup with oil and meat. There were kinds of soup in which vegetables such as chard was included. Sometimes the flour was fried and a slurry obtained by adding water. This kind of soup was called sawiq. Sometimes milk was also used instead of water. Occasionally, suet was used too (Khalīl ibn Ahmad, I, 483; Abū Dāwūd, Adab, 103; Ibn Manzūr, VI, 273; Shāmī, VII, 304).

\subsection{Sugar and Deserts}

During The Prophet Muhammad's time, sugar from sugarcane was consumed, sugar and almond were littered around the guests during weddings. Manna which has been a secretion from a tree from Sinnā, Syria and the Euphrates basin were brought to Madīnah (Haisamī, IV, 53; Ibn al-Jawzī, I, 147; Kettānī, II, 270).

A desert prepared by mixing dried dates with milk was liked by The Prophet Muhammad. With no doubt, honey was mostly consumed desert (Bukhārī, At'ima, 32, Tibb, 4). A desert prepared with flour, oil and honey called fallūzaj was from foreign 
cultures. His friend Usmān, the forth caliph, introduced this desert to the people of Madinnah and Arabs liked it a lot. He was a merchant and barrowed this desert from Sassānid's kitchen. Dates were also added as ingredient to this desert by Arabs. This desert was prepared by Usmān and served to The Prophet Muhammad and he liked it (Tabarānī, XVII, 336).

\subsection{Fruits}

Dates were mostly consumed fruit. Water melon, melon, grape and quince were common too. Peach, pomegranate, mulberry and fig were also reported to be consumed. Nuts such as peanut and almonds were also known in Madinah. The Prophet Muhammad neutralized the sweetness of dates with gherkin (Ibn Māja, At'ima, 38; Tirmidhī, At'ima, 35; Shāmī, VII, 310, 319, 321, 322).

\subsection{Eggs and Dairy Products}

The Prophet Muhammad once ate egg from ostrich. In Madinnah, the chicken strolled around in the streets. With no doubts, egg from chicken was an important food stuff. Cheese was not known in Madīnah however, curd was consumed. The Prophet Muhammad ate a kind of fermented cheese which had been produced in that region during Tabūq excursion (A.H. 9/A.D. 630) and he liked it. Milk from camel, sheep and goat were mostly consumed and they were consumed raw. Milk run off in hot days were mixed with water to make it easy to drink (Ibn Abū Shaiba, II, 418; Abū Dāwūd, At'ima, 39, Tibb, 20; Shāmī, VII, 306).

\section{The Tools Utilized in the Kitchen of Muhammad's Time}

When we consider Kitāb al-Zuhd (Islamic Asceticism: a part of hadiths book) alone that we encountered in the hadith culture, it is possible to think that a cuisine was not established at that time. However, when hadith corpus was investigated as a whole, it is obvious that the cuisine was formed in relation to the demands and the opportunities that shaped according to the tradition. In this context, tools for cooking and preparing drinks had a crucial role. They were mentioned as follows in accordance with some headings:

\subsection{Plates}

During The Prophet Muhammad era, vessels with different dimensions were utilized for consuming foods. Among these vessels, dasi'a, jafna, qas'a, maktala, safha, faiha and sukurruja were some examples.

Dasi'a was a vessel to serve big amount of foods. Twenty people could eat from this vessel (Ālūsī, I, 387).

Jafna was a vessel for feeding seven to ten people. Dough could be mixed in this vessel also and it was used for soup (Khalīl ibn Ahmad, I, 93; Ibn Sa'd, I, 388, III, 614).

Qas'a was a vessel feeding four people and maqtala was for two to three people (Ibn Māja, At'ima, 10; Ālūsī, I, 387; Jawād Ali, V, 66). Safha and faiha were small vessels only for one person (Khalīl ibn Ahmad, II, 971, III, 1427; Ālūsī, I, 387). There are some opinions supporting the idea that these vessels were for two or three people. Sukurruja was the smallest in dimension. It was used for snacks (Ālūsī, I, 387).

\subsection{Pots}

The names such as mirjal, burma can be encountered in the texts. Mirjal was a copper vessel. Copper vessels were used to reserve water however because of the odor from copper vessel, it was not recommended to perform al-wudü' with the water from this vessel. It was possible that there were no tinning practice therefore poisoning was possible (Jawād Ali, V, 65; Akgün, p. 58).

Garra was a big vessel with handles carried by four people. Meat such as from sheep was cooked in this vessel. Burma was a basalt saucepan used for cooking. Stone pots made up of basalt rocks which were revealed in archaeological excavation in Yaman's Faw region were used in several regions of Arabian Peninsula. Qidr al-Musahhana was this kind of pots coming from that region (Abū Dāwūd, At'ima, 17; Akgün, p. 58).

Crockery with green glaze called Hantam or Jarr al-Ahdar were brought from Yaman and Egypt. There were also crockeries called buram and saidan (Abū Dāwūd, Ashriba, 9; Akgün, p. 58).

\subsection{Leather Bottles}


Leather bottles formed by stitching feet and head parts were used to preserve goods such as water, honey, fat. Ukka, misāb and badī which were used to preserve butter, curd and dried curd were main types of leather bottles used for preserving goods. Ukka was small in dimension for butter and honey. The vessels called haifa and misāb were used for honey. Haifa was narrow on the top and wide at the bottom and made up of leather. Misāb was also from leather (Tabarānī, XXV, 120; Ibn Manzūr, IX, 101, X, 468).

Leather bottles were made up of tanned leather from several animals and fat was preserved in it. One of the animals whose skin was utilized was lizard. The Prophet Muhammad did not like meat from lizard. Moreover he did not like things preserved in lizard's skin. He asked about the origin of butter in the bread which was served to him and when he learnt that the butter was preserved in lizard's skin, he preferred not to eat this bread (Ibn Māja, At'ima, 47).

\subsection{Water Vessels}

Although Arabs gave special names for vessels for preserving water, these vessels were also used for eating. As an example nabīz was preserved in the same vessel used for water and sometimes suet was preserved also in it. The vessel that contains water enough for twenty people, was called tibn or tebn. Sahn was smaller in dimension than this one. The water vessel for three or four people were called uss. Goblets were deep and it reserved two or two and half times more water than today's goblets. Qa'b was enough for only one person. Gumar was the name given to the smallest of water vessels (Ālūsī, I, 394; Akgün, p. 60).

In Arabian Society, vessels made up of gold and silver existed. In the Qur'ān, gold (Zuhruf 43/71) and silver (Insān 76/15) goblets were mentioned. The Prophet Muhammad recommended not to eat and drink from gold and silver vessels. These were replaced by goblets commonly from wood and rarely from glass because of its expense in daily use. The Prophet Muhammad had a glass goblet (Muslim, Libās, 1, 4; Ibn Māja, Ashriba, 27; Nasāī, Zīnah, 87).

The water vessels made up from wood were also called jumjuma. Wooden water vessels were made up of tamarisk or nudar. Nudar was softened by burying under the soil and carved to obtain the goblet. These were dehydrated by the time and cracked. This kind of water vessel used by The Prophet Muhammad were inherited to Anes and passed to his daughter from Anes. Anes served water, milk, honey syrup and wort to The Prophet Muhammad by it. Because this water vessel cracked, Anes filmed its sorrounding with silver. Some of these vessels had iron handles to hang on the wall to make sure that any kind of insects did not fall into them (Bukhārī, Ashriba, 29; Ibn Māja, At'ima, 27; Ahmad ibn Hanbal, III, 247).

Some of the wooden vessels were made up of date's trunk. A vessel called naqiir which was carved from trunk was mostly used to prepare wort. When wort was kept in this vessel few days, the rate of alcohol was increased. Therefore at first The Prophet Muhammad prohibited to prepare wort in this vessel but later he allowed in case of paying attention to the duration of keeping in this vessel (Muslim, Ashriba, 6; Ibn Māja, Ashriba, 14; Tirmidhī, Ashriba, 5, 6).

During traveling, water vessels from leather were used because it was easy to carry and keep. These were generally called qirbah. These were made up by tanning the skin from slaughtered or hunted animals. The dimensions varied according to the need. Some of them were made with the skin of animal as a whole by modeling feet parts as pacifier. Some of them were made by dividing the skin into smaller parts (Ibn Māja, Ashriba, 13; Ibn Kathīr, VI, 104; Shāmī, VII, 364).

Big leather bottles were utilized in the region since Jahiliyya Period. It was mentioned in narratives that Abd al-Muttalib and his sons served water in a pool made up of leather to the pilgrims who came to Qa'bah and they even added some grapes to the water to aromatize it. Most probably, leather was supported from sides and fixed onto a basis to obtain a wide mouthed water vessel. These were called shacb. During traveling, water vessel made up of half of a camel skin were used (Ibn Sa'd, I, 83, VIII, 319; Ibn Hajar, VIII, 248).

Some vessels were made up of ceramic. Vessels in red colors existed. The color came from the soil they made up of. The green and white color vessels were also mentioned in narratives. These were bituminized from outside to make them resistant to be broken. They were called muzaffat or muqayyar (Shāmī, VII, 362; Ibn Hajar, IV, 417).

The vessels were also made up of gourd. These vessels called dubbā' and qar' were in the shape of cantharus. The wort was preserved in them. This may cause formation of wine. Therefore, The Prophet Muhammad prohibited to preserve wort in vessels such as dubbā' (Muslim, Ashriba, 6; Tirmidhī, Ashriba, 5). The names of water vessel which were encountered in the texts were idāa, zekwa, ziqq, and ka's (Khalīl ibn Ahmad, I, 72, II, 756, 757, III, 1547). 


\section{Conclusion}

The Prophet Muhammad who was described as a person who ate and drank in Qur'ān made the best use of every provisions offered by his environment. Occasionally, he did not personally prefer some foods. He obeyed the prohibitions from Allah such as not drinking alcohol and not eating pork, and meat slaughtered not in the name of Allah. It was understood that most prominent foods in Arabic Peninsula in context of cusine were meat, milk and some vegetables. It was concluded that wheat was consumed rarely however barley was the mostly used grain. It was determined that the meat were fried, boiled or marinated and milk was consumed raw, the most prominent vegetables were mushroom, zucchini and chard. The tools used in the kitchen varied richly according to the needs.

\section{References}

[1] Abū Dāwūd, Suleimān ibn al-Ashās al-Sijistānī (1969-1974), (d. A.D. 888), Sunan Abū Dāwūd (ed. Izzat Ubayd al-Duās-Ādil al-Sayyid), I-V, Homs.

[2] Ahmad ibn Hanbal, Abū Abd-Allah Ahmad ibn Muhammad ibn Hanbal al-Shaybānī al-Marwazī (1991), Musnad Ahmad ibn Hanbal (ed. Abd-Allah Muhammad al-Darwīsh), I-XI, Beirut.

[3] Akgün, Sevim Demir (2007), Hz. Peygamber Döneminde Yemek Kültürü (Unpublished master thesis, Sakarya University, Institute Social Sciences), Sakarya.

[4] Ālūsī, Abū al-Meālī Jamāl al-Dīn Mahmūd Shukrī (d. A.D. 1924), Bulūg al-Areb fĩ Márifati Ahvāl al-Arab (ed. Muhammad Bahcet al-Aserī), I-III, Beyrut, ts.

[5] Bukhārī, Muhammad ibn Ismāīl (1979), (d. A.D. 870), al-Jāmi‘ al-Sahīh, I-VIII, Istanbul.

[6] Haisamī, Nūr al-Dīn Ali ibn Abū Bakir, (1967), Majma' al-Zawāid ve Manba' al-Fawāid, I-X, Beirut.

[7] Ibn Abū Shaiba, Abd Allah ibn Muhammad al-Qūfĩ (1994), (d. A.D. 849), al-Musannaf fĩ al-Ahādīs wa al-Āsār (ed. Saīd al-Lihām), I-VIII, Beirut.

[8] Ibn al-Jawzī, Jamāl al-Dīn Abū al-Faraj Abd al-Rahmān ibn Ali (1992), al-Muntazam fĩ Tārīh al-Umam wa alMulūk (ed. Muhammad Abd al-Kādir Atā-Mustafa Abd al-Kādir Atā), I-XVIII, Beirut.

[9] Ibn Hajar al-Asqalānī (1992), (d. A.D. 1448), al-Isāba fī Tamyīz al-Sahāba (ed. Ali Muhammad al-Bajāwī), I-VIII, Beirut.

[10] Ibn Kathīr, Abū al-Fidā Ismāīl ibn Umar (1997-1999), (d. A.D. 1373), al-Bidāya wa al-Nihāya (ed. Abd Allah ibn Abd al-Muhsin al-Turkī), I-XXI, Cīze.

[11] Ibn Māja, Abū Abd Allah Muhammad ibn Yazīd (1992), al-Sunan (ed. Muhammad Fuād Abd al-Bākī), I-II, 2nd edition, İstanbul.

[12] Ibn Manzūr, Abū al-Fadl Muhammad ibn Mukarram ibn Ali al-Ansārī (1980-1990), Lisān al-Arab, I-XVI, Beirut.

[13] Ibn Sa'd, Muhammad (1985), (d. A.D. 884), al-Tabaqāt al-Qubrā (ed. Ihsān Abbās), I-IX, Beirut.

[14] Jawād Ali (1976-1978), al-Mufassal fĩ Tārīh al-Arab Qabl al-Islām, I-X, Beirut.

[15] Kettānī, Muhammad Abū al-Hayy ibn Abd al-Kabīr (19??), al-Tarātīb al-Idāriyyah, l-Il, Beirut.

[16] Khalīl ibn Ahmad, Abū Abd al-Rahmān al-Farāhadī (1994), (d. A.D. 791), Kitāb al-Ayn (ed. Mahdī al-MahzūmīIbrāhīm al-Sāmarrāī), I-III, Beirut.

[17] Muslim, Abū al-Husain al-Hajjāc al-Kushairī (1992), al-Jāmi' al-Sahīh, (ed. Muhammad Fuād Abd al-Bākī), I-III, 2nd edition, İstanbul.

[18] Nasāī, Abū Abd al-Rahmān Ahmad ibn Shuaib (1992), Kitāb al-Sunan al-Kubrā, I-VIII, 2nd edition, İstanbul.

[19] Shāmī Muhammad ibn Yūsuf al-Sālihī (1990), Subul al-Hudā wa al-Rashād fĩ Sīrati Hair al-'Ibād (ed. Mustafa Abd al-Wāhid), I-VIII, Cairo.

[20] Tabarānī, Abū al-Qāsim ibn Ahmad (1983) (d. A.D. 971), al-Mu'jam al-Kabīr (ed. Abd al-Majīd al-Salafī), l-XXX, 2nd edition, Mawsil.

[21] Tirmidhī, Muhammad ibn Īsā al-Dahhāk (1975-1978), (d. A.D. 892), al-Sunan al-Tirmidhī (ed. Ahmad Muhammad Shākir) Cairo. 